\title{
ENSAIO DE IMPACTO CHARPY EM MATRIX EPOXÍDICA REFORÇADA COM FIBRAS CONTÍNUAS DE FIQUE*
}

\author{
Giulio Rodrigues Altoé \\ Maria Carolina Andrade Teles ${ }^{1}$ \\ Marcos Vinícius Fonseca Ferreira ${ }^{1}$ \\ Gilson Vieira Fernandes ${ }^{1}$ \\ Frederico Muylaert Margem ${ }^{2}$ \\ Sergio Neves Monteiro ${ }^{3}$
}

\section{Resumo}

Fibras de fique (Furcraea Andina) estão entre as lignocelulósicas naturais com grande potencial para utilização em compósitos poliméricos. O presente trabalho avalia a resistência ao impacto deste tipo de compósito com matriz epoxídica reforçada com diferentes percentuais de fibras de fique. As fibras foram embutidas sob pressão em mistura com resina epóxi DGEBA/TETA curada à temperatura ambiente por 24 horas. Os corpos de prova normalizados foram confeccionados com percentuais de até $30 \%$ em volume de fibras de fique alinhadas ao longo de todo o comprimento, estes corpos de prova foram então ensaiados em pêndulo de impacto Charpy e as superfícies de fratura analisadas por microscopia eletrônica de varredura, MEV. A resistência ao impacto aumentou substancialmente com a quantidade relativa de fibra de fique reforçando o compósito. Este desempenho foi associado à dificuldade de ruptura imposta pelas fibras bem como ao tipo de trincas resultantes da interação fibra de fique/matriz epoxídica que ajuda a absorver a energia do impacto.

Palavras-chave: Fibra de fique; Impacto charpy; Compósito epoxídicos; MEV.

\section{CHARPY IMPACT TESTS IN EPOXY MATRIX COMPOSITES REINFORCED WITH CONTINUOUS FIQUE FIBER}

\section{Abstract}

Fique Fibers (Furcraea Andina) are among the lignocellulosic natural with great potential for use in polymer composites. This study evaluates the impact resistance of this type of epoxy matrix composite reinforced with different percentages of fique fibers. The fibers were embedded under pressure mixed with DGEBA / TETA epoxy resin cured at room temperature for 24 hours. Standard samples were prepared up to $30 \%$ by volume of fique fibers aligned along its entire length, these specimens were then tested in Charpy pendulum impact and the fracture surfaces examined by scanning electron microscopy, SEM. The impact resistance increased substantially with the relative amount of fique fiber reinforcing the composite. This performance was associated with the rupture difficulty imposed by the fibers and by the type of cracks resulting from the interaction of fique fiber / epoxy matrix that help absorb impact energy.

Keywords: Fique fiber; Charpy impact; Epoxi composite; SEM.

1 Graduando(a) em Engenharia Metalúrgica e de Materiais, bolsista de iniciação científica, LAMAV, UENF, Campos dos Goytacazes, Rio de Janeiro - Brasil.

2 Engenheiro de Produção, Doutor em Ciência e Engenharia de Materiais, Pós-Doutorando, LAMAV, UENF, Campos dos Goytacazes, Rio de Janeiro - Brasil.

3 Engenheiro Metalúrgico, Doutor em Ciência e Engenharia de Materiais, Professor titular, IME, Rio de Janeiro, Rio de Janeiro - Brasil. 


\section{INTRODUCTION}

Cellulose-based fibers are being used due to its "green" image, according to Kalia, Kaith e Kaurs (1). Instead of glass fibers, widely used in modern technology, the lignocellulosic fibers are renewable and can be incinerated at the end of material useful life without the addition of air pollution, since the amount of $\mathrm{CO} 2$ liberated during the incineration is negligible compared to the amount absorbed by the plant throughout its life.

Even if the industrial processing of an equivalent release of $\mathrm{CO} 2$ is added, the lignocellulosic fiber can be considered neutral with respect to the emission of gases responsible for global warming (2).

Environmental aspects are related to the fact that natural fibers are renewable, recyclable and biodegradable. Moreover, their composites require comparatively less energy to be processed. These combined aspects results in carbon dioxide neutrality of the natural fiber in contrast to synthetic fibers that contribute to global warming through their positive emission of $\mathrm{CO} 2(3,5)$. The economical advantage of lignocellulosic fibers is their significantly lower prices in confront with glass fiber, which is the cheapest among the synthetic fibers.

Technical aspects could also be in favor of the natural fibers that are softer and, consequently, less abrasive to processing equipments. Furthermore, for some lignocellulosic fibers, the mechanical properties can be superior to the corresponding one of glass fiber composites $(4,5)$. This is the particular case of lignocellulosic fibers that have received a surface treatment to improve adhesion to a polymeric matrix (5). Natural fibers also present drawbacks in relation to the use as composite reinforcement. The high moisture adsorption at surface owing to the hydrophilic characteristic of the fiber causes incompatibility with hydrophobic polymeric matrices (6).

Previous works demonstrate that the incorporation of lignocellulosic fibers in polymeric matrix gives rise to composites with mechanical resistance directly proportional of the fiber content, where these fibers act as reinforcement for matrix due to their high mechanical properties. Therefore, the objective of this study was to evaluate the mechanical properties of epoxy matrix composites reinforced with continuous and aligned fique fibers in the charpy impact tests.

\section{EXPERIMENTAL PROCEDURE}

Supplied by a producer in Colombia, the basic material used in this work was the fiber extracted from the leaf of fique plant (Furcraea Andina), Fig. 1(a). No treatment was applied on fique fibers, Fig. 1(b). 

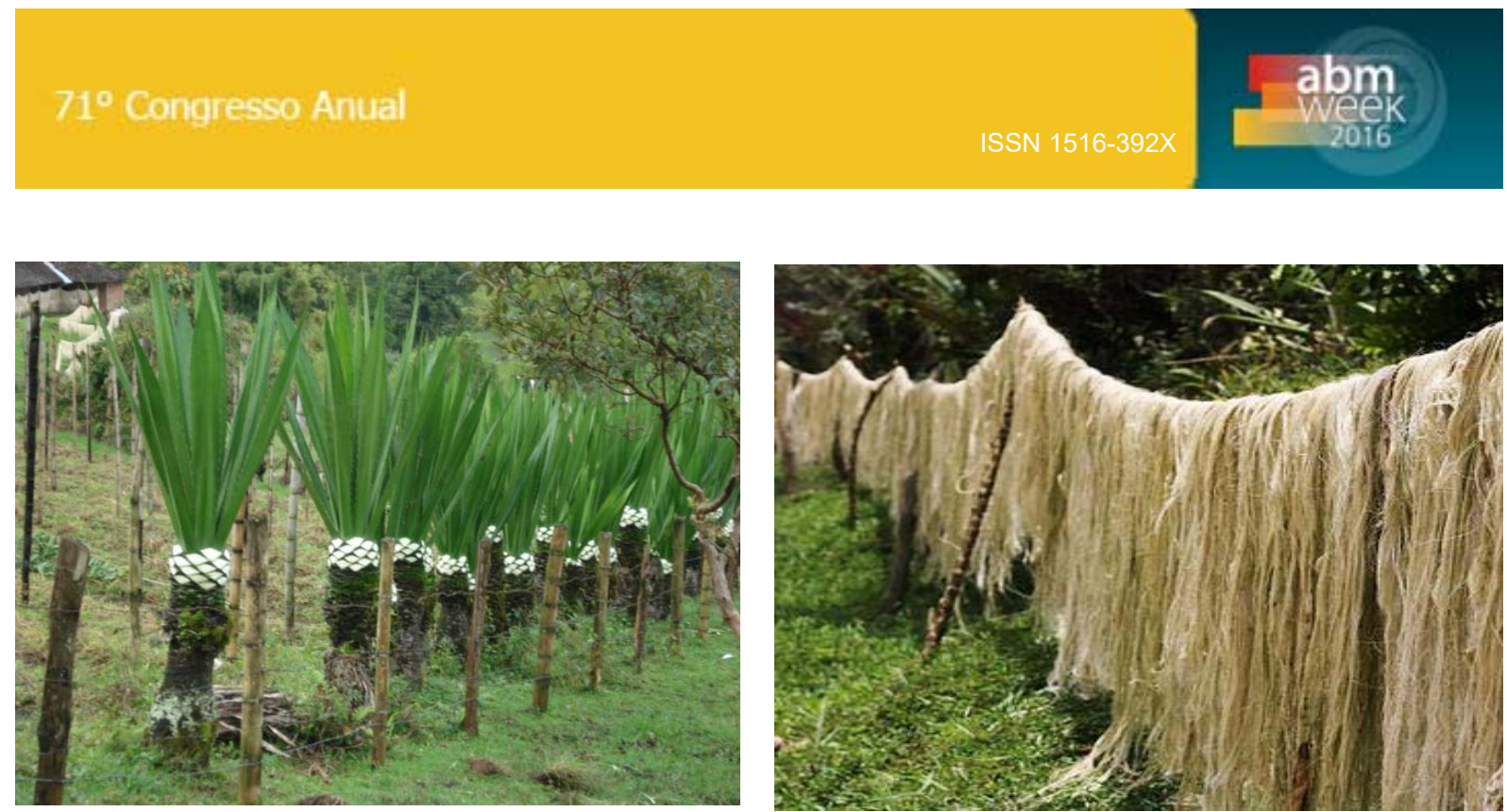

Figure 1. Fique plant and its fibers, respectively.

Was used too a commercially available, Dow Chemical, type diglycidyl ether of the bisphenol-A (DGEBA) epoxy, 187.3 g/equiv, resin hardened with stoichiometric, phr 13 , trietylene tetramine (TETA), applied as matrix. The composites with $0 \%, 10 \%, 20 \%$ and $30 \%$ in volume of aligned fique fibers were manufactured through accommodation of the fibers in a rectangular mold $152 \times 122 \times 10 \mathrm{~mm}$ and soaked with the epoxy resin to complete the cavity under 10 ton of pressure to ensure the correct impregnation between the resin and fibers. A 24 hours cure at room temperature was allowed for these composite samples and the procedure origins plates with were cut following the ASTM standard. So then, specimens for each percentage of fique fiber composite were impact tested in a PANTEC pendulum - as Fig. 2 - and set in the Charpy configuration.

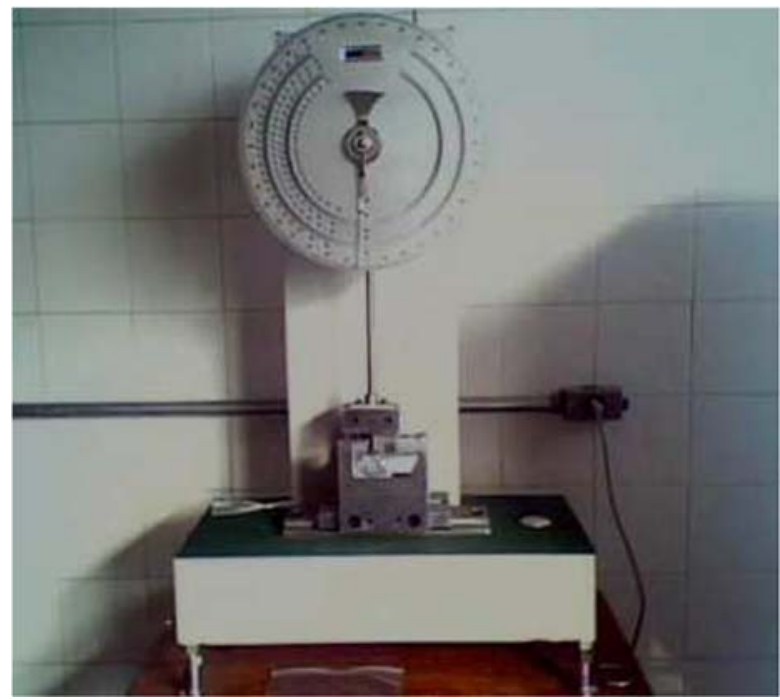

Figure 2. Pantec impact pendulum.

\section{RESULTS AND DISCUSSION}

The table 1 presents the results of Charpy Impact Tests of epoxy matrix composites reinforced with different volume fractions of fique fibers. 
Table 1. Charpy Impact Energy for epoxy composites reinforced with fique fibers

\begin{tabular}{lc}
\hline $\begin{array}{l}\text { Amount of } \\
\text { Fiber (wt.\%) }\end{array}$ & Fique \\
\hline 0 & $14.9 \pm 0.6$ \\
\hline 10 & $14.9 \pm 1.8$ \\
\hline 20 & $14.9 \pm 2.1$ \\
\hline 30 & $42.8 \pm 2.7$ \\
\hline
\end{tabular}

Based on the results shown in Table 1, the variation of the Charpy Impact Energy with the amount of fique fibers in the epoxy matrix is shown in Figure 3.

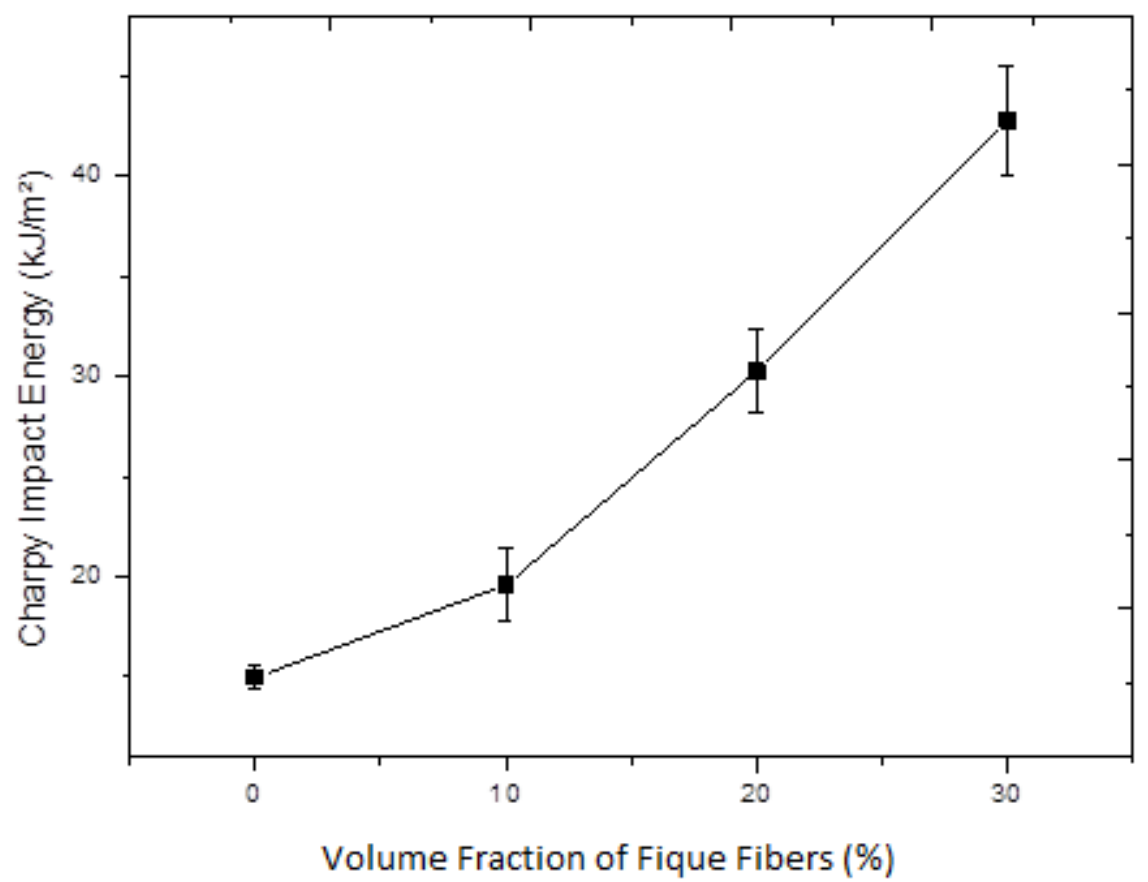

Figure 3. Charpy Impact Energy as a function of amount Fique fibers.

In this figure it should be noticed that the fique fibers incorporation into the epoxy matrix significantly improves the impact toughness of the composite. Within the standard deviation, this improvement can be considered as a linear function with respect to the amount fiber up to $30 \%$. The values shown in this figure are consistent with results reported in the literature. The reinforcement of a polymeric matrix with both synthetic $(13,14)$ and natural $(7,8)$ fibers increases the impact toughness of the composite. The table 2 compares values of Charpy impact energy of different polymers composites with some lignocellulosic fibers. 
Table 2. Charpy Impact toughness of polymeric composites reinforce with natural fibers

\begin{tabular}{lcc}
\hline $\begin{array}{c}\text { Composites with } \mathbf{3 0 \%} \text { in } \\
\text { volume of continuous and } \\
\text { aligned fibers }\end{array}$ & $\begin{array}{c}\text { Charpy } \mathbf{I m p a c t ~ T o u g h n e s s} \\
\left(\mathbf{k J} / \mathbf{m}^{2}\right)\end{array}$ & Reference \\
\hline fique/epoxy & 42.8 & This work \\
\hline ramie/epoxy & 16.6 & $(9)$ \\
\hline ramie/polyester & 79.1 & $(10)$ \\
\hline coir/polyester & 18.9 & $(11)$ \\
\hline coir/epoxy & 13.7 & $(11)$ \\
\hline curaua/polyester & 13.4 & $(12)$ \\
\hline curaua/epoxy & 8.1 & $(12)$ \\
\hline
\end{tabular}

The relatively low interface strength between a hydrophilic natural fiber and a hydrophobic polymeric matrix contributes to an ineffective load transfer from the matrix to a longer fiber. This results in relatively greater fracture surface and higher impact energy is spent for the rupture (15). Another factor is the flexural compliance of a long fiber during the impact test, which will be further discussed. The macroscopic aspects of the typical specimen ruptured by Charpy impact tests are shown in Figure 4 . In this figure it should be noted that the incorporation of aligned fique fibers results in a marked change with respect to pure epoxy ( $0 \%$ fiber) in which a totally transversal rupture occurs.

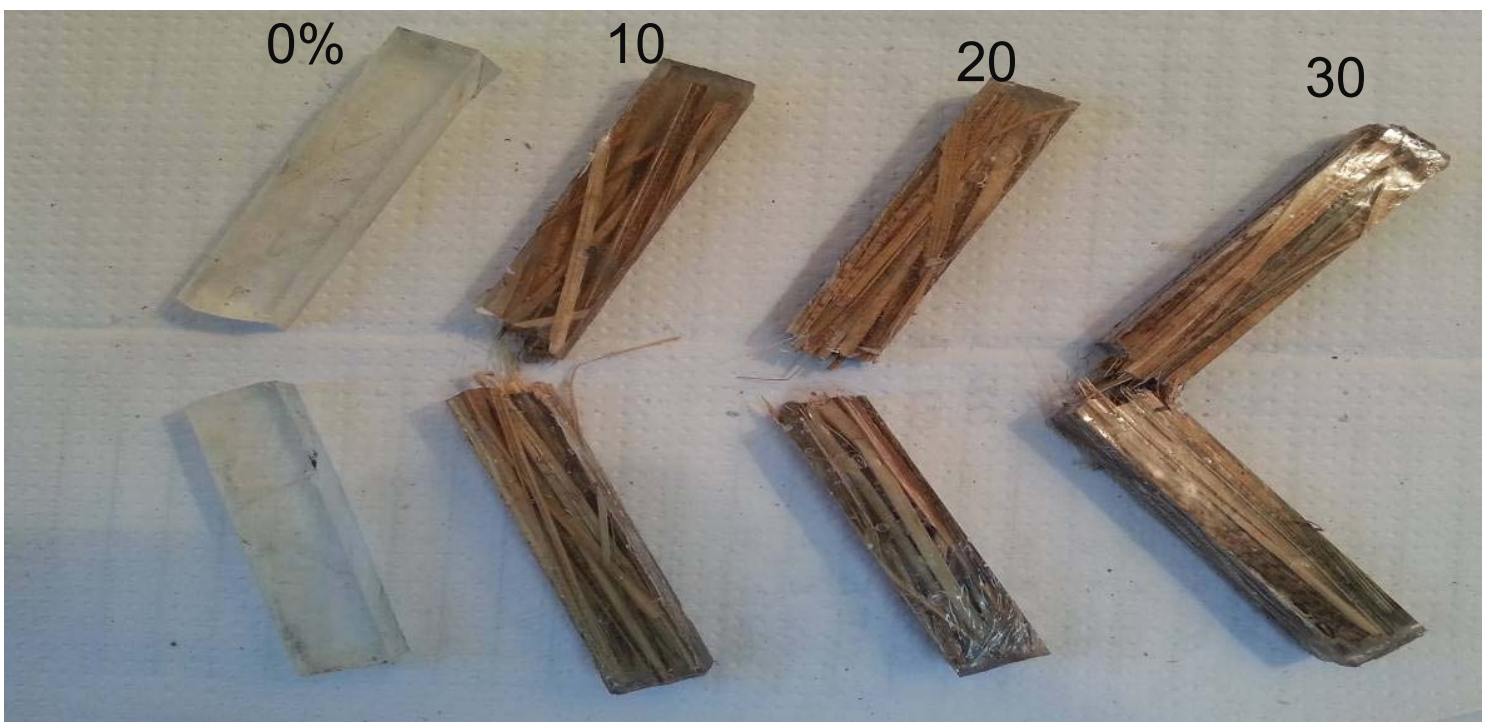

Figure 4. Typical macrostructural aspects of Charpy specimens of epoxy composites reinforced with different volume fractions of fique fiber.

The specimen with $30 \%$ in volume of fique fibers was not completely broken upon impact. This is due to the relatively high tensile strength characteristic of the fique fiber, which avoids a total collapse. For these larger fiber fractions, the impacted specimen is bent enough to allow the hammer to continue its trajectory, while the two parts of the folded specimen remained attached. The non-occurrence of rupture upon impact indicates a high toughness of the composite. Was assumed that if the rupture had occurred, the absorbed energy would be even higher. 


\section{CONCLUSION}

Epoxy matrix composites reinforced with continuous and aligned fique fibers show an improvement in the strength as compared to the pure epoxy matrix.

The epoxy matrix incorpored with $30 \%$ of fique fiber significantly improves the toughness of the compiste, $43 \mathrm{~kJ} / \mathrm{m}^{2}$, as compared to pure epoxy resin, with $15 \mathrm{~kJ} / \mathrm{m}^{2}$. Much of this increase in toughness is apparently due to low interfacial shear band fiber/epoxy matrix tensioned. This results in greater energy absorbed as a result of propagation of longitudinal cracks along the interface, which leads to larger areas of rupture in comparison with a transverse fracture.

\section{Acknowledgements}

The authors thank the support to this investigation by the Brazilian agencies: CNPq, CAPES and FAPERJ.

\section{REFERENCES}

1 S. Kalia, B. S. Kaith, I. Kaurs, Cellulose Fibers: Bio - and Nano - Polymer Composites (New York: Springer, 2011).

2 A. Gore, An Inconvenient Truth. The Planetary Emergency of Global Warming and What We Can do About It (Emmaus, Pennsylvania, USA: Rodale Press, 2006).

3 R. Zah, R. Hischier, A.L. Leão and I. Braun, "Curaua fibers in the automobile industry A sustainability assessment" J. Cleaner Production, 15 (2007) 1032-1040.

$4 \quad$ P. Wambua, I. Ivens, I.Verpoest, "Natural fibers: can they repalce glass and fibre reinforced plastics?", Composites Science and Technology, 63 (2003) 1259-1264.

5 A.K. Mohanty, M. Misra and G. Hinrichsen, "Biofibers, biodegradable polymers and biocomposites: an overview", Macromolecular Mat. And Engineering, 276/277 (2000), 1-24.

6 A. Vasquez, J. Riccieri, L. Carvalho, "Interfacial properties and initial step of water sorption in uniderectional unsaturated polyester/vegetable fibre composites". Polymer Composites, 20 (1999) 29-27.

7 A.L. Leão, I.H. Tan and J.C. Caraschi, "Curaua fiber - A tropical natural fibre from Amazon - Potential and applications in composites", Proceedings of the International Conference on Advanced Composites, (Hurghada, Egypt, May, 1998) 557-564.

8 S.N. Monteiro, R.C.M.P. Aquino, F.P.D. Lopes, E.A. Carvalho and J.R.M. d'Almeida, "Charpy impact notch toughness of piassava fibers reinforced polyester matrix composites" (in Portuguese), Rev. Mater., 11(3) (2006) 204-210.

9 S.N. Monteiro, F.M. Margem, L.F.L. Santos Jr.,"Impact tests in epoxy matrix composites reinforced with ramie fibers'(in Portuguese), Proceedings of the 64rd International Congress of the Brazilian Association for Metallurgy and Materials (Belo Horizonte, Brazil, July, 2009) 1-9.

10 S.N. Monteiro, F.M. Margem, L.F.L. Santos Jr.,"Impact tests in polyester matrix composites reinforced with ramie fibers'(in Portuguese), Proceedings of the 63rd International Congress of the Brazilian Association for Metallurgy and Materials (Santos, Brazil, July, 2008) 1-12.

11 S.N Monteiro, L.L. Costa, H.P.G. Santafé, "Characterization of the Charpy impact resistance of coir fiber reinforced epoxy matrix composites " (in Portuguese), Proceedings of the 18th Brazilian Congress on Materials Science and Engineering CBECIMAT (Porto de Galinhas, PE, Brazil, November, 2008) 1-12.

12 S.N. Monteiro, F.P.D. Lopes, "Impact tests in Curaua fibers reinforced polymeric composites", Proceedings of the 62nd International Congress of the Brazilian 
13 S.Y. Fu, B. Lauke, E. Mäder, X. Hu and C.Y. Yue, "Fracture resistance of short-glassfiber-reinforced and short-carbon-fiber-reinforced poly-propylene under charpy impact load and dependence on processing", J. Mater. Process. Technol., 89/90 (1999), 501507.

14 MONTEIRO, S.N.; PEREIRA, A.C.; INÁCIO, W. P.; Izod impact energy of polyester matrix composites reinforced with aligned sisal fibers. In: Associação Brasileira de Metalurgia e Materiais - ABM, São Paulo, SP, Julho, 2011, p. 1-12.

15 C.Y. Yue, H.C. Looi and M.Y. Quek, "Assessment of Fiber-Matrix Adhesion and Interfacial Properties Using the Pullout Test". Int. J. of Adhesion and Adhesives, 15 (1995), 73-80. 